\title{
Novel variant in the leptin receptor (LEPR) gene and its association with fat quality, odour and flavour in sheep
}

\author{
A. Gunawan ${ }^{1 *}$, F. W. Pramukti ${ }^{1}$, K. Listyarini ${ }^{1}$, M.A. Abuzahra ${ }^{1}$, J. Jakaria ${ }^{1}$, \\ C. Sumantri ${ }^{1}$, I. Inounu ${ }^{2}$ and M. J. Uddin ${ }^{3}$ \\ ${ }^{1}$ Department of Animal Production and Technology, Faculty of Animal Science, \\ IPB University, Jl. Agatis, Dramaga Campus, Bogor 16680 - Indonesia \\ ${ }^{2}$ Center Research for Development of Animal Husbandry, \\ Jl. Raya Pajajaran Kav. E-59, Bogor 16151 - Indonesia \\ ${ }^{3}$ School of Veterinary Science, The University of Queensland, \\ Gatton Campus, Gatton Qld 4343 - Australia \\ *Corresponding E-mail: aagun4780@gmail.com
}

Received July 08, 2018; Accepted November 22, 2018

\begin{abstract}
ABSTRAK
Tujuan dari penelitian ini adalah untuk menginvestigasi asosiasi dan mengukur ekspresi gen LEPR sebagai kandidat gen untuk kualitas sifat perlemakan, odour dan flavour pada daging domba. Total 47 domba jantan digunakan pada penelitian ini. Komposisi asam lemak, BCFA (Branch Chanin Fatty Acids; MNA, MP, MOA, dan EOA) dan skatole (MI) yang merepresentasikan kualitas perlemakan, sifat odour dan flavour diukur pada domba jantan umur 10-12 bulan. Identifikasi mutasi baru gen LEPR dan analisis ekspresi gen pada perbedaan kandungan kualitas perlemakan, sifat odour dan flavour dianalisis berturutturut menggunakan PCR RFLP dan qRT-PCR. SNP pada daerah genomik g.40854778 A>C gen LEPR berasosiasi dengan kualitas perlemakan; asam lemak jenuh asam trikosanoat (C23:0) dan asam tetrakosanoat (C24:0) dan asam lemak tak jenuh asam dokosaheksaenoat (C22:6n3), sementara mutasi gen LEPR tidak ditemukan adanya asosiasi ( $\mathrm{P}>0.05)$ dengan sifat odour dan flavour (MNA, MI, MP, MOA, dan EOA) pada daging domba. Hasil ekspresi mRNA gen LEPR lebih tinggi $(\mathrm{P}<0.01)$ pada domba dengan genotipe AA. Hasil penelitian ini dapat disimpulkan bahwa mutasi gen LEPR berkontribusi terhadap kandungan asam lemak tanpa mempengaruhi sifat odour dan flavour pada domba.
\end{abstract}

Kata kunci: flavour, LEPR, ekspresi mRNA, odour, mutasi

\section{ABSTRACT}

The aim of this study was to investigate the association and expression of LEPR with fat quality, flavour and odour in sheep. A total of 47 rams were used in this study. Fatty acids composition, BCFA (Branch Chanin Fatty Acids; MNA, MP, MOA, and EOA) and skatole (MI) representing fat quality, flavour and odour in sheep were measured at ages of 10-12 months old. Identification of novel variant and expression analysis of LEPR gene with different fat quality, odour and flavour were performed by PCR RFLP and qRT-PCR, respectively. A SNP in genomic region g.40854778 A $>C$ of the LEPR gene was associated $(\mathrm{P}<0.05)$ with fat quality of saturated fatty acids (SFA) including [tricosanoic acid (C23:0) and tetracosanoic acid (C24:0)] and poly unsaturated fatty acid (PUFA) [docosahexaenoic acid $(\mathrm{C} 22: 6 \mathrm{n} 3)]$. However, the novel variant of LEPR was not significantly associated $(\mathrm{P}<0.05)$ with fat content, odour and flavour (MNA, MP, MOA, EOA, and MI). The mRNA expression analysis showed 
that LEPR mRNA expression was higher $(\mathrm{P}<0.01)$ in sheep found at the AA genotype. It could be concluded that variant SNP in the LEPR may contribute to fatty acid composition without influencing odour and flavour traits in sheep.

Keywords: flavour, LEPR, $m R N A$ expression, odour, variant

\section{INTRODUCTION}

Fat quality, sheep meat odour, and flavour are regarded as important components of the edible meat quality of sheep (Pleasants et al., 2005; Pethick et al., 2005). Fat quality in these regard fat content and fatty acid composition may decrease in lean meat of animals due to declining levels of saturated fatty acids (SFA) and increased levels of phospholipids and polyunsaturated fatty acids (PUFA) (Wood, 1984). For odour and flavour, two chemical compounds mainly branch chain of fatty acid (BCFA; BCFAs; 4methyloctanoic (MOA), 4-ethyloctanoic (EOA) and 4-methylnonanoic acids) and skatole (MI; 4methylindole) have often associated with odour and flavour, respectively (Watkins et al., 2014; Ran-Ressler et al., 2014). Improvement of meat quality including fat quality, odour and flavour is a critical factor in the protection and development of markets for sheep. However, these traits can usually be measured post-slaughter and often had low heritabilities (Boukha et al., 2011). Selection on the basis of molecular genetic of candidate gene approached through identification variant analysis (SNPs) was most effectively implemented for breeding programs (van der Steenet et al., 2005). Identification of novel SNPs within genes influencing fat quality, odour and flavour traits and their association and gene expression could be the important and generally applied tools to predict the genetic merit of sheeps.

As part of the search for genetic contributors to fat quality and sheepmeat odour and flavour, whole genome approaches using RNA sequencing had revealed leptin receptor (LEPR) as a gene with differential expression in sheeps divergent for fatness traits (Gunawan et al., 2018). Leptin receptors (LEPR) were expressed in the olfactory mucosa and upregulated by fasting (Baly et al., 2007). Furthermore, LEPR were found in the olfactory bulb and the piriform cortex (Bennet et al., 1998). In animal model of mice, leptin could modulate olfactory-mediated preingestive behavior through leptin receptors (Gechell et al., 2006). In humans, a gender specific relation between leptin and the ability to identify an odour was observed (Karlsson et al., 2002). In livestock, SNP detection of the LEPR gene in cattle had been associated with somatic cells count (Kulig and Kmieć, 2009), milk performance (Anton et al., 2012), reproduction traits (Almeida et al., 2003) and growth traits (Kulig and Kmieć, 2009). However, there was no study investigating the association and expression of LEPR with fat quality like fatty acid composition, sheepmeat odour and flavour in sheep, especially in Indonesian sheep. Functional and positional studies suggested that these genes could be important candidate genes for fat quaity, odour and flavour compounds in sheep. The aims of this study were to analyse the novel variant of LEPR genes and to unravel the association and expression of these genes with fat quality, odour and flavour in sheep.

\section{MATERIALS AND METHODS}

\section{Animals and Phenotypes}

Forty seven Indonesian sheeps including fattailed sheep (JFT, $\mathrm{n}=20$ ), thin-tailed sheep (JTT, $\mathrm{n}=17$ ), and Garut composite (GCS, $\mathrm{n}=10$ ) sheep were used in this study. Indonesian sheeps are dominated with JFT and JTT which are distributed in all of region Indonesia. The sheep were caged in group and were given fattening feed ad libitum. Samples were taken from loin tissue and were collected from the rams with body weight between $25-30 \mathrm{~kg}$ and ages between 10-12 months old. The animals were slaughtered in the slaughter house according to the standard operasional procedure provided in the house. Data of carcass and meat quality were determined according to reference methods for assessment of physical characteristic of meat (Honikel et al, 1998). The loin was taken approximatelly of 500 grams for fatty acid (FA) analysis, 500 grams for odour and flavour analysis, and $30 \mathrm{mg}$ loin for DNA extraction. All samples for the DNA extraction were immidiately placed in ice and kept at the temperature of $-20^{\circ} \mathrm{C}$ until futher usages. 
Fatness Traits: Fat Content and Fatty Acid Analysis

Muscle samples of approximately $100 \mathrm{~g}$ were collected for the analysis needs of fatness traits including fat content and fatty acid (FA). Fatty acid content was measured for each sample using the extraction method according to Folch et al., (1957) procedure. The FA composition was quantified using gas chromatography (GC-2010 GC-2010 Plus-Shimadzu according AOAC 2001). The fatness traits were expressed as a proporsion of the total FAs included fat content, saturated fatty acid (SFA), monounsaturated fatty acid (MUFA) and polyunsaturated fatty acid (PUFA).

\section{Odour and Flavour Analysis}

Due to the limitations of loin muscle samples from sheep, analyses of odour and flavour compounds were carried out on loin samples from javanese fat tailed (JFT, $n=22)$. The odour and flavours compounds were extracted using LikensNicerson method which was a combination of distillation and extraction with solvent simultaneously using Gas Chromatography Mass Spectophotometry (GC-MS) tool. The phenotypes of odour and flavour were measured including MNA (4-methylnonanoic), MP (4-methylphenol), MOA (4-methyloctanoic), EOA (4-ethyloctanoic) and MI (3-methylindole) refereed to Listyarini et al. (2018).

\section{SNP Discovery of LEPR Gene}

The SNP of LEPR used in this study were based on RNA sequencing study (Gunawan et al., 2018). Using RNA deep sequencing analysis, our group describing several single nucleotide polymorphisms (SNPs) have been described recently by our group by comparing loin muscles unsaturated fatty acids contents. Among them, a SNP of LEPR (g.40854778 A>C) gene was selected for this association study. For this purpose, the Indonesian sheep population $(n=47)$ were genotyped. Amplification of LEPR gene fragments were conducted using polymerase chain reactions (PCR). Amplification process of PCR began denaturation step at $94^{\circ} \mathrm{C}$ for five minutes. The second phase consists of 35 cycles, each cycle consisting of denaturation process at $94^{\circ} \mathrm{C}$ for 10 seconds, primer annealing at temperatures $57^{\circ} \mathrm{C}$ for LEPR gene and DNA extension at $72^{\circ} \mathrm{C}$ for 30 seconds. The final stage was the primer extension at $72{ }^{\circ} \mathrm{C}$ for ten minutes. The genotyping was performed by PCR-RFLP method. The PCR product was analyzed using $1.5 \%$ agarose gel (Fischer Scientific Ltd) and digested by using the restriction enzymes of AciI for LEPR (New England Biolabs). Digested PCR-

Table 1. GenBank Accession Numbers and Primer Sequences

\begin{tabular}{|c|c|c|c|c|c|c|c|c|}
\hline $\begin{array}{l}\text { Gene } \\
\text { Name }\end{array}$ & $\begin{array}{l}\text { Accession } \\
\text { Number }\end{array}$ & Primer Sequence & Application & $\begin{array}{l}\text { Size } \\
\text { (bp) }\end{array}$ & $\begin{array}{l}\mathrm{Tm} \\
\left({ }^{\circ} \mathrm{C}\right)\end{array}$ & Enzyme & SNP & $\begin{array}{c}\text { Digested } \\
\text { Fragments } \\
\text { Length (bp) }\end{array}$ \\
\hline LEPR & NC_019458.2 & $\begin{array}{l}\text { F: 5'- GAT GAC } \\
\text { CTG ACA TAT CCA } \\
\text { GG-3' } \\
\text { R: 5'- CAA TGA } \\
\text { AGT GGG GAA } \\
\text { AGG AC-3' }\end{array}$ & Genotyping & 432 & 60 & Aci 1 & $\begin{array}{c}\text { g. } \\
40761 \\
672 \\
A>C\end{array}$ & $\begin{array}{l}\text { AA : } 432 \\
\text { CC }: 292 \\
\text { and } 140 \\
\text { AC }: 432, \\
292 \text { and } \\
140\end{array}$ \\
\hline LEPR & $\begin{array}{l}\text { NM_0010097 } \\
63.1\end{array}$ & $\begin{array}{l}\text { F: 5'- GAA GCC } \\
\text { TGA TCC ACC ATT } \\
\text { AG -3' } \\
\text { R: 5'- GAG } \\
\text { CAA GAG } \\
\text { GGA TG -3 }\end{array}$ & qRT-PCR & 239 & 60 & & & \\
\hline GAPDH & NC_019460.2 & $\begin{array}{l}\text { F: 5'- GAG AAA } \\
\text { CCT GCC AAG TAT } \\
\text { GA -3' } \\
\text { R: 5'- TAC CAG } \\
\text { GAA ATG AGC } \\
\text { TTG AC-3 }\end{array}$ & qRT-PCR & 203 & 62 & & & \\
\hline
\end{tabular}


RFLP products were resolved in $2 \%$ agarose gel. The details of PCR-RFLP pattern, GenBank accession number and primer sequences used in this study were listed in Table 1 .

\section{mRNA Expression of LEPR Gene}

The sample tissues from nine sheep liver with different fat quality, odour and flavour were isolated for mRNA study base on genotype results. The nine sheep were divided into three groups $\mathrm{AA}, \mathrm{AC}$, and $\mathrm{CC}$ genotype. The differential gene expression between genotypes was performed using PROC GLM test in SAS. For the qRT-PCR analysis, cDNA was synthesized using SuperScript II reverse transcriptase (Invitrogen). Gene specific primers for LEPR for the qRT-PCR were designed by using the Primer3 software (Rozen and Skaletsky, 2000) (Table 1). In each run, the 96-well microtiter plate contained each cDNA sample and no-template control. The qRT-PCR was performed with the following program according to Gunawan et al., (2013a and 2013b). The housekeeping genes (GAPDH) were used for reference of the target genes (Table 1).

\section{Statistical Analysis for Fatness Traits: Fat Content and Fatty Acid Traits}

The association of LEPR gene with fatness traits; fat content and fatty acid compositions was performed by General Linier Model (GLM) using SAS. 9.2 softwere. The model of GLM was follows:

$$
\mathrm{Y} i j k=\mu+\mathrm{G}_{i}+\mathrm{B}_{j}+\mathrm{E}_{i j k}
$$

Where, Yijk was the fatness traits; fat content and fatty acid traits, $\mu$ was overall mean, $\mathrm{G}_{i}$ was the fixed effect of $\mathrm{i}$-th genotype $(\mathrm{i}=\mathrm{AA}, \mathrm{AC}$, and $\mathrm{CC})$ and $B_{j}$ was the fixed effect of $j$-th breed $(j=J F T$, JTT and GCS) and $E_{i j k}$ is the residual error. Least square mean values for the loci genotypes were compared by t-test and p-values were adjusted by the Tukey-Kramer correction (Kayan et al., 2011; Cinar et al., 2012).

\section{Statistical Analysis for Sheepmeat Odour and Flavour}

Due to the limitation of odour and flavour analysis, the study was conducted in javanese fat tailed (JFT). The association of LEPR gene with sheepmeat odour and flavour was performed by General Linier Model (GLM) using SAS. 9.2 softwere. The model of GLM was:

$$
\mathrm{Y}_{i j}=\mu+\mathrm{G}_{i}+\mathrm{E}_{i j}
$$

Where, $\mathrm{Y}_{i j}$ was the odour and flavour, $\mu$ is overall mean, $\mathrm{G}_{i}$ was the fixed effect of $\mathrm{i}$-th genotype ( $\mathrm{i}=\mathrm{AA}, \mathrm{AC}$, and $\mathrm{CC}$ ) and $\mathrm{E}_{i j}$ was the residual error. Least square mean values for the loci genotypes were compared by t-test and pvalues were adjusted by the Tukey-Kramer correction (Kayan et al., 2011; Cinar et al., 2012).

\section{Analyis of LEPR Gene Expression}

The delta $\mathrm{Ct}(\Delta \mathrm{Ct})$ method was used for calculating the difference between target gene and the reference genes: $\left(\Delta \mathrm{Ct}=\mathrm{Ct}_{\text {target }}-\mathrm{Ct}_{\text {housekeeping }}\right.$ genes) as described previously by Silver et al., (2003). The results of graph were calculated as fold change calculated from delta Ct-values. The phenotypic differences between high and low fat quality, odour and flavour of LEPR gene expressions were compared using $t$ tests. The significant values $(\mathrm{P}<0.05)$ were considered statistically to indicate the significant differences.

\section{RESULTS}

\section{Novel Variant SNP of LEPR Gene}

SNP of LEPR at posistion g.40854778 A $>$ C was succesfully genotyped in Indonesian sheep populations. The SNP g. $40854778 \mathrm{~A}>\mathrm{C}$ of LEPR was polymorphism: $432 \mathrm{bp}$ for the $\mathrm{CC}$ genotype, 432, 292, and $140 \mathrm{bp}$ for the AC, 292 and $140 \mathrm{bp}$ for AA genotype (Figure 1). Three genotypes of $\mathrm{AA}, \mathrm{AC}$, and $\mathrm{CC}$ were found in this study. The genotype frequency of LEPR (g.40854778 A>C) was detected in Hardy Weinberg Equlibrium (HWE) $(\mathrm{P}<0.05)$. The gene frequencies including genotype and allele frequency of LEPR were presented in Table 2.

\section{Association Analysis between LEPR Genotyped and Fatness, Odour and Flavour of Sheeps}

Association analysis of the g.40854778A $>C$ SNP with fat quality revealed significant $(\mathrm{P}<0.05)$ associations with saturated fatty acids including tricosanoic acid (C23:0), tetracosanoic acid (C24:0), and polyunsaturated fatty acid (C22:6n3) (Table 3). Sheep with homozygous ' $C C$ ' genotypes were associated with higher polyunsaturated fatty acids [docosahexaenoic acid $(\mathrm{C} 22: 6 \mathrm{n} 3)]$ and higher saturated fatty acid [tricosanoic acid (C23:0) and tetracosanoic acid (C24:0)] (Table 3). However, the LEPR gene (g.40854778A $>$ C) had no significant effect $(\mathrm{P}>0.05)$ with fat content (Table 3$)$ and any of the sheepmeat odour and flavour compound (Table 


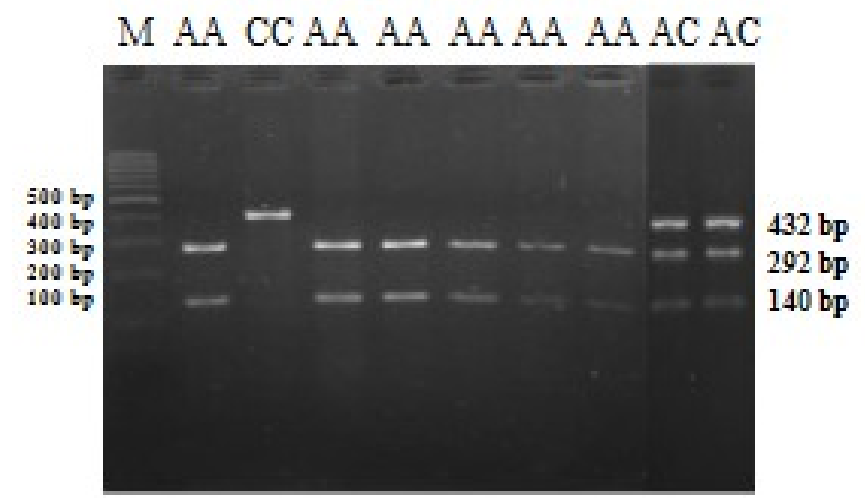

Figure 1. PCR-RFLP Genotyping Result for the LEPR Gene. $M=100 \mathrm{bp}$ markers. 1,3, 4,5,6,7 = AA genotype. $3=\mathrm{CC}$ genotype. $8,9=\mathrm{AC}$ genotype

Table 2. The Number of Animals per Genotype and Allele Frequency of Each SNP

\begin{tabular}{|c|c|c|c|c|c|c|c|}
\hline \multirow{2}{*}{ Sample } & \multirow{2}{*}{$\mathrm{N}$} & \multicolumn{3}{|c|}{ Genotype Frequency } & \multicolumn{2}{|c|}{ Allele Frequency } & \multirow{2}{*}{$\begin{array}{c}\text { Chi-squared } \\
\left(\chi^{2}\right)\end{array}$} \\
\hline & & $\overline{\mathrm{AA}}$ & $\mathrm{AC}$ & $\mathrm{CC}$ & $\mathrm{A}$ & $\mathrm{C}$ & \\
\hline Indonesian sheep & 47 & $0.66(31)$ & $0.28(13)$ & $0.06(3)$ & 0.8 & 0.2 & $0.02 *$ \\
\hline
\end{tabular}

*=significant at $\mathrm{P}<0.05$

4). This gene was not associated with all the phenotypes including MNA, MP, MOA, EOA, and MI (Table 4).

\section{mRNA Expression of LEPR in Different Fatty Acid Composition}

Higher mRNA expression was detected in the loins muscle of sheeps with the AA genotype $(\mathrm{P}<0.05)$ compared to the $\mathrm{AC}$ and $\mathrm{CC}$ genotypes (Figure 2). The genotype of AA (high PUFA docosahexaenoic acid (C22:6n3) and lower SFA tricosanoic acid (C23:0), as well as tetracosanoic acid (C24:0) was different compared to genotypes of AC and CC (low PUFA docosahexaenoic acid (C22:6n3), and higher SFA tricosanoic acid (C23:0), as well as tetracosanoic acid (C24:0) in the muscle.

\section{DISCUSSION}

This study showed that the LEPR gene at g.40854778 A $>$ C polymorphism was significantly associated $(\mathrm{P}<0.05)$ with saturated fatty acid (SFA), tricosanoic acid (C23:0) and tetracosanoic acid (C24:0), and polyunsaturated fatty acid
(PUFA) docosahexaenoic (C22:6n3). Sheep with AA genotype had lower tricosanoic acid (C23:0) and tetracosanoic acid (C24:0) than AC and CC genotypes (Table 3). However, the highest content of unsaturated fatty acid docosahexaenoic acid (C22:6n3) was sheep with AA genotype. Docosahexaenoic acid (C22:6n3) and oleic acid $(\mathrm{C} 18: \ln 9 \mathrm{c})$ were able to reduce the toxic effects of 7-ketocholesterol (7KC), thought to contribute to reduce risk of neurodegenerative disease and age-related diseases (Debbabi et al., 2017). Previous study reported an association of LEPR with fatty acid composition in pigs (Oliveira et al., 2017; Rodriguez et al., 2016). Roddriguez et al., (2016) reported that LEPR gene was significantly associated $(\mathrm{P}<0.05)$ with saturated fatty acids (SFA); C14:0, C16:0, C18:0, C20:0, monounsaturated fatty acid (MUFA); C20:1n-9, and polyunsaturated fatty acid (PUFA); C20:4n-6 in fattening Duroc pig. LEPR gene in was associated with fatty acid composition in muscle (Oliveira et al., 2017).

The LEPR gene (g.40854778A $>$ C) had no significant effect $(\mathrm{P}>0.05)$ with fatness trait fat content (Table 3 ) and any of the sheepmeat odour 
Table 3. Genotypes and Association Analysis of LEPR Gene

\begin{tabular}{|c|c|c|c|}
\hline \multirow[b]{2}{*}{ Fatness Trait } & \multicolumn{3}{|c|}{ Genotypes } \\
\hline & $\begin{array}{c}\text { AA } \\
(n=31)\end{array}$ & $\begin{array}{c}\mathrm{AC} \\
(\mathrm{n}=13)\end{array}$ & $\begin{array}{c}\mathrm{CC} \\
(\mathrm{n}=3)\end{array}$ \\
\hline Fat content & $6.03 \pm 3.93$ & $4.77 \pm 2.65$ & $4.75 \pm 4.90$ \\
\hline Lauric acid (C12:0) & $0.53 \pm 0.70$ & $0.32 \pm 0.41$ & $0.40 \pm 0.26$ \\
\hline Myristic acid (C14:0) & $3.70 \pm 2.21$ & $2.36 \pm 1.33$ & $3.83 \pm 3.26$ \\
\hline Myristoleic acid (C14:1) & $0.15 \pm 0.07$ & $0.08 \pm 0.05$ & $0.13 \pm 0.07$ \\
\hline Pentadecanoic acid (C15:0) & $0.50 \pm 0.17$ & $0.51 \pm 0.12$ & $0.51 \pm 0.09$ \\
\hline Palmitic acid (C16:0) & $19.00 \pm 2.80$ & $17.86 \pm 1.87$ & $18.21 \pm 5.76$ \\
\hline Palmitoleic acid (C16:1) & $1.73 \pm 0.37$ & $1.50 \pm 0.28$ & $1.37 \pm 0.60$ \\
\hline Heptadecanoic acid (C17:0) & $1.08 \pm 0.35$ & $1.10 \pm 0.44$ & $0.94 \pm 0.26$ \\
\hline Stearic acid (C18:0) & $12.51 \pm 4.41$ & $15.74 \pm 6.24$ & $15.61 \pm 5.10$ \\
\hline Elaidic acid (C18:1n9t) & $0.10 \pm 0.11$ & $0.09 \pm 0.10$ & $0.05 \pm 0.09$ \\
\hline Oleic acid $(\mathrm{C} 18: \ln 9 \mathrm{c})$ & $27.99 \pm 4.23$ & $27.00 \pm 4.19$ & $24.68 \pm 8.57$ \\
\hline Linoleic acid (C18:2n6c) & $2.23 \pm 0.96$ & $2.26 \pm 0.78$ & $2.42 \pm 1.76$ \\
\hline Arachidic acid (C20:0) & $0.08 \pm 0.04$ & $0.10 \pm 0.05$ & $0.10 \pm 0.11$ \\
\hline Eicosedienoic acid (C20:2) & $0.04 \pm 0.02$ & $0.04 \pm 0.02$ & $0.05 \pm 0.01$ \\
\hline Behenic acid (C22:0) & $0.02 \pm 0.02$ & $0.02 \pm 0.02$ & $0.05 \pm 0.07$ \\
\hline Arachidonic acid (C20:4n6) & $0.44 \pm 0.41$ & $0.46 \pm 0.33$ & $0.93 \pm 1.15$ \\
\hline Tricosanoic acid (C23:0) & $0.007 \pm 0.01^{\mathrm{b}}$ & $0.01 \pm 0.01^{\mathrm{ab}}$ & $0.03 \pm 0.03^{\mathrm{a}}$ \\
\hline Tetracosanoic acid (C24:0) & $0.006 \pm 0.016^{\mathrm{b}}$ & $0.01 \pm 0.01^{\mathrm{ab}}$ & $0.03 \pm 0.05^{\mathrm{a}}$ \\
\hline Docosahexaaonic (C22:6n3) & $0.04 \pm 0.05^{\mathrm{ab}}$ & $0.02 \pm 0.0^{3 \mathrm{~b}}$ & $0.09 \pm 0.005^{\mathrm{a}}$ \\
\hline Fatty Acid Total & $71.17 \pm 5.94$ & $70.55 \pm 5.14$ & $70.30 \pm 10.10$ \\
\hline Saturated Fatty Acid (SFA) & $37.57 \pm 5.83$ & $38.19 \pm 7.50$ & $39.89 \pm 5.37$ \\
\hline Monounsaturated Fatty Acid (MUFA) & $30.37 \pm 4.65$ & $29.11 \pm 4.65$ & $26.43 \pm 9.09$ \\
\hline Polyunsaturated Fatty Acid (PUFA) & $3.11 \pm 1.39$ & $3.12 \pm 1.11$ & $3.89 \pm 2.99$ \\
\hline
\end{tabular}

Mean \pm SD are units of percentage fatty acid composition. ${ }^{a b}$ Mean value with different superscript letters in the same row differ significantly at $\mathrm{P}<0.05$

and flavour compound (Table 4). This gene was not associated with all the phenotypes odour and flavour including MNA (4-methylnonanoic), MP (4-methylphenol), MOA (4-methyloctanoic), EOA (4-ethyloctanoic), and MI (3-methylindole). Odour and flavour differences were not only a matter of LEPR gene function, but also considered in close reliance on memory, learning and sensory function (Stevenson et al., 2010).
However, we could speculate that the LEPR gene may be positively correlated with odour and flavour compounds in sheep.

The mRNA of LEPR was differentially regulated $(\mathrm{P}<0.05)$ between sheep with $\mathrm{AA}$ genotype (high PUFA docosahexaenoic acid (C22:6n3) and lower SFA tricosanoic acid (C23:0) and tetracosanoic acid (C24:0)) compared to the $\mathrm{AC}$ and $\mathrm{CC}$ genotypes (low PUFA 
Table 4. Genotypes and Asociation Analysis of LEPR Gene with Flavour and Odour Compounds

\begin{tabular}{ccrrr}
\hline \multirow{2}{*}{ Polymorphism } & Odour and Flavour & \multicolumn{3}{c}{ Genotypes $(\mu \pm$ S.E $)$} \\
\cline { 3 - 5 } & Compound $(u g / g)$ & \multicolumn{1}{c}{ AA $(\mathrm{n}=14)$} & \multicolumn{1}{c}{ AC $(\mathrm{n}=5)$} & \multicolumn{1}{c}{ CC $(\mathrm{n}=3)$} \\
\hline \multirow{2}{*}{ LEPR } & MNA & $0.485 \pm 0.183$ & $0.135 \pm 0.112$ & $0.103 \pm 0.081$ \\
& MP & $20.240 \pm 3.520$ & $27.810 \pm 6.040$ & $20.007 \pm 0.478$ \\
& MOA & $0.094 \pm 0.029$ & $0.346 \pm 0.320$ & $0.037 \pm 0.021$ \\
& EOA & $0.394 \pm 0.119$ & $0.471 \pm 0.190$ & $0.068 \pm 0.037$ \\
& MI & $0.314 \pm 0.092$ & $0.215 \pm 0.081$ & $0.073 \pm 0.043$ \\
\hline
\end{tabular}

$\mathrm{MNA}=4$-methylnonanoic, $\mathrm{MP}=4$-methylphenol, $\mathrm{MOA}=4$-methyloctanoic, $\mathrm{EOA}=4$-ethyloctanoic, $\mathrm{MI}=$ 3-methylindol

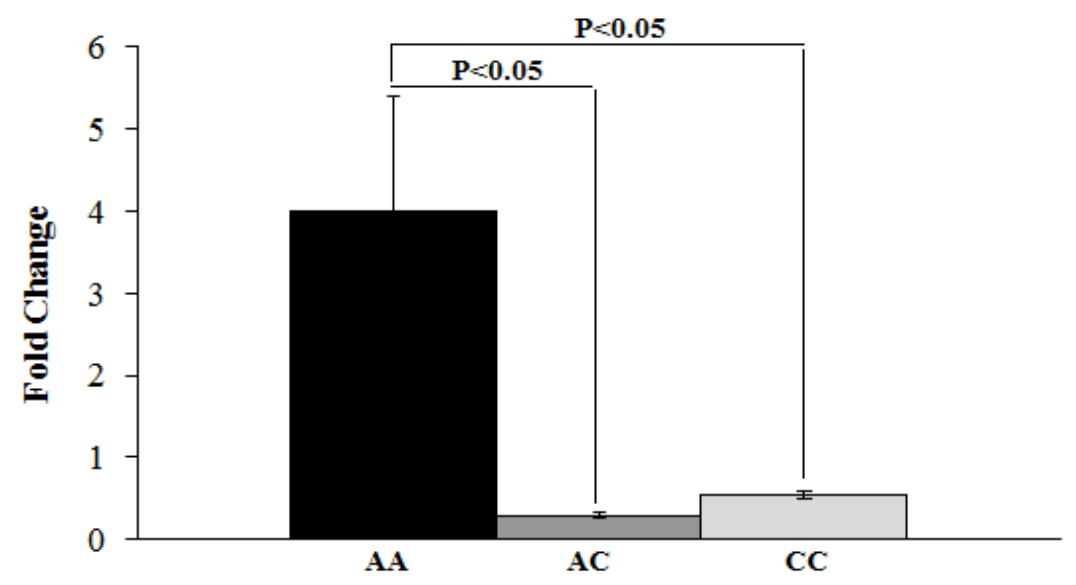

Figure 2. mRNA Expression of LEPR Gene in the Liver with Different Fatty Acid Composition

docosahexaenoic acid (C22:6n3) and higher SFA tricosanoic acid (C23:0), and tetracosanoic acid $(\mathrm{C} 24: 0))$ in the loin muscle (Figure 2). The LEPR was expressed mainly in hypothalamus, the centre of the energy homeostasis and the regulation of secretory organs activity (Matteis et al., 2012). Leptin deficiency leads to extreme obesity in both mice and humans, while leptin treatment of wildtype mice reduced fat mass (Scwartz et al., 2017; Coll et al., 2007). At the levels of LEPR mRNA and plasma leptin were highly linked with adipocyte cell size and cellular fat content (Skurk et al., 2007; Jernas et al., 2006). The LEPR and the stearoyl-CoA desaturase (SCD) were two of genes playing important role in controling fatness including fatty acid traits. LEPR as a catalyze of the leptin hormone influenced overall fatness
(Houseknecht et al., 1998), while SCD ratelimiting was important enzyme for fatty acid composition for the biosynthesis of MUFA from SFA (Ntambi \& Miyazaki, 2004). Higher transcript abundance of LEPR in high PUFA composition might cause shift in fatty acid metabolism via up-regulating the LEPR gene. It could be suggested as the evidence that the Indonesian sheep showed good on fatness traits and were beneficial for human health. These were due to higher PUFA docosahexaenoic acid (C22:6n3) and lower SFA tricosanoic acid (C23:0) and tetracosanoic acid (C24:0). However, this study should need validation in other animal populations in order to evaluate its potential in selective breeding sheeps. 


\section{CONCLUSION}

Associatios and expression of Leptin Receptor (LEPR) gene polymorphisms with fatness traits, odour and flavour were described for the first time in Indonesian sheep, providing evidence that LEPR might be an important candidate gene for fatty acids composition. The LEPR might play a role in fatty acids composition validated through association study and by profiling of mRNA expression in liver tissues. The association study of odour and flavour through LEPR association has not been detected yet. In addition, this study needs to be validated in other animal populations in order to evaluate its potential in selective breeding.

\section{ACKNOWLEDGMENTS}

This work were supported by KP4S project Number: $\quad 76.60 /$ PL.040/H.1/04/2017.K from Ministry of Agriculture, Republic of Indonesia and KLN project Number 079/SP2H/LT/DRPM/II/2016 from the Ministry of Research and Higher Education of Republic of Indonesia.

\section{REFERENCES}

Almeida, S.E.M., E.A. Almeida, J.C.F. Moraes and T.A. Weimer. 2003. Molecular markers in the LEP gene and reproductive performance of beef cattle. J. Anim. Breed. Genet. 120 (2):106-113.

Anton, I., K. Kovács, G. Holló, V. Farkas, F. Szabó, I. Egerszegi, J. Rátky, A. Zsolnai and K.P. Brüssow. 2012. Effect of DGAT1, leptin and TG gene polymorphisms on some milk production traits in different dairy cattle breeds in Hungary. Archiv Tierzucht, 55 (4):307-414.

Baly C., J. Aioun, K. Badonnel, M.C. Lacroix, D. Durieux, C. Schlegel, R. Salesse and M. Caillol. 2007. Leptin and its receptors are present in the rat olfactory mucosa and modulated by the nutritional status. Brain Res. 1129(1):130-141.

Bennett, P.A., K. Lindell, C. Karlsson, I.C. Robinson, L.M. Carlsson and B. Carlsson. 1998. Differential expression and regulation of leptin receptor isoforms in the rat brain: effects of fasting and oestrogen. Neuroendocrinol. 67(1):29-36.

Boukha, A., V. Bonfatti, A. Cecchinato, A. Albera,
L. Gallo, P. Carnier and G. Bittante. 2011. Genetic parameters of carcass and meat quality traits of double muscled Piedmontese cattle. Meat Sci. 89(1):84-90.

Cinar, M.U., A. Kayan, M.J. Uddin, E. Jonas and D. Tesfaye. 2012. Association and expression quantitative trait loci (eQTL) analysis of porcine AMBP, GC and PPP1R3B genes with meat quality traits. Mol Biol Rep. 39(4):4809-4821.

Coll, A.P., I.S. Farooqi, and S. O'Rahilly. 2007. The hormonal control of food intake. Cell. 129:251-262.

Debbabi, M., A. Zarrouk, M. Bezine, W. Meddeb, T. Nury, A. Badreddine, E.M. Karym, R. Sghaier, L. Bretillon, S. Guyot, M. Samadi, M. Cherkaoui-Malki, B. Nasser, M. Mejri , S. Ben-Hammou, M. Hammami and G. Lizard. 2017. Comparison of the effects of major fatty acids present in the Mediterranean diet (oleic acid, docosahexaenoic acid) and in hydrogenated oils (elaidic acid) on 7-ketocholesterolinduced oxiapoptophagy in microglial BV-2 cells. Chem. Phys. Lipids. 207:151-170.

Folch, J., M. Lee and G. Sloane-Stanley. 1957. A simple method for the isolation and purification of total lipids from animal tissues. J. Biol. Chem. 226:497-509.

Getchell, T.V, K. Kwong, C.P. Saunders, A.J. Stromberg and M.L. Getchell. 2006. Leptin regulates olfactory-mediated behavior in ob/ob mice. Physiol. Behav. 87(5):848-56.

Gunawan, A., S. Sahadevan, C. Neuhoff, C. Große-Brinkhaus, A. Gad, L. Frieden, D. Tesfaye, E. Tholen, C. Looft, M.J. Uddin and K Schellander. 2013a. RNA deep sequencing reveals novel candidate genes and polymorphisms in boar testis and liver tissues with divergent androstenone levels. PLoS one. 8(5): 63259.

Gunawan, A., S. Sahadavan, M.U. Cinar, C. Neuhoff, C. Große-Brinkhaus, L. Frieden, D. Tesfaye, E. Tholen, C. Looft, D.S Wondim, M. Hölker, K. Schellander and M.J. Uddin. 2013b. Identification of the novel candidate genes and variants in boar liver tissues with divergent skatole levels using RNA deep sequencing. PLoS one. 8(8):e72298.

Gunawan, A., Jakaria, K. Listyarini, A. Furqon, C. Sumantri, S.H. Akter and M.J. Uddin. 2018. Transcriptome signature of liver tissue with divergent sheepmeat odour and flavour 
using RNA deep sequencing. Gene. 67:8694.

Honikel, K.O. 1998. Reference methods for the assesment of physical of meat. 49 (4):447-57

Houseknecht, K. L., C.A. Baile, R. L. Matteri and M.E. Spurlock. 1998. The biology of leptin: A review. J. Anim. Sci. 76: 1405-1420.

Jernås, M., J. Palming, K Sjoholm, E. Jennische, P.A. Svensson, B.G. Gabrielsson, M. Levin, A. Sjogren, M. Rudemo, T.C. Lystig, B. Carlsson, L.M. Carlsson and M. Lonn. 2006. Separation of human adipocytes by size: Hypertrophic fat cells display distinct gene expression. FASEB J. 20(9):1540-1542.

Karlsson A.C., A.K. Lindroos, L. Lissner, J.S. Torgerson, B. Carlsson, L. M. Carlsson and L. Sjostrom. 2002. Evidence for genderspecific associations between leptin and olfaction. J. Gend. Specif. 5(6):25-32.

Kayan, A., M.U. Cinar, M.J. Uddin, C. Phatsara, K. Wimmers, S. Ponsuksili, D. Tesfaye, C. Looft, H. Juengs, E. Tholen, and K. Schellander. 2011. Polymorphism and expression of the porcine Tenascin $\mathrm{C}$ gene associated with meat and carcass quality. Meat Sci. 89(1):76-83.

Kulig, $\mathrm{H}$ and M. Kmieć, 2009. Association between leptin gene polymorphisms and growth traits in Limousin cattle. Russian J. Genet 45(6): 738-741.

Listyarini, K., Jakaria' M. J. Uddin, C. Sumantri and A. Gunawan. 2018. Association and Expression of CYP2A6 and KIF12 Genes related to Lamb Flavour and Odour. Trop. Anim. Sci. J. 41(2):100-107

Matteis, G., M.C. Scatà, F. Grandoni, F. Petrera, F. Abeni., G. Catillo, F. Napolitano and B. Moioli, 2012. Association analyses of single nucleotide polymorphisms in the leptin and leptin receptor genes on milk and morphological traits in Holstein cows. OJAS 2(3): 174-182

Ntambi, J and M. Miyazaki. 2004. Regulation of stearoyl-CoA desaturases and role inmetabolism. Prog. Lipid Res. 43(2):91104.

Oliveira, M.I.A., B.R. Martins, D. Alberton, E.A.S. Ramos, G. Picheth and F.G.M. Rego. 2017. Type 2 diabetes-associated genetic variants of FTO, LEPR, PPARg, and TCF7L2 in gestational diabetes in a Brazilian population. Arch. Endocrinol. Metab. 61(3):238-248.

Pethick, D.W., D.L. Hopkins, D.N. D'Souza, J.M.
Thompson and P.J. Walker. 2005. Effects of animal age on the eating quality of sheep meat. Aust. J. Exp. Agr. 45:491-498.

Pleasants, A. B., J.M. Thompson and D.W. Pethick, 2005. A model relating a function of tenderness, juiciness, flavour and overall liking to the eating quality of sheep meat. Aust. J. Exp. Agr. 45(5): 483-489.

Ran-Ressler, R. R., S. Bae, P. Lawrence, D.H. Wang and J.T. Brenna. 2014. Branchedchain fatty acid content of foods and estimated intake in the USA. Br. J. Nutr. 112(4):565-572.

Rodriguez, E. H., L. Bosch, R.N. Pena RN and Estany. 2016. The effect of SCD and LEPR genetic polymorphism on fat content and composition is maintained throughout fattening in durog pigs. Meat Sci. 121:33-39.

Rozen, S and H. Skaletsky. 2000. Primer3 on the www for general users and for biologist programmers. Methods Mol. Biol. 132:36586.

Schwartz, M. W., R.J. Seeley, L.M. Zeltser, A. Drewnowski, E. Ravussin, L.M. Redman and R.L. Leibel. 2017. Obesity pathogenesis: An endocrine society scientific statement. Endocr. Rev. 38(4):267296.

Silver, N., S. Best, J. Jiang and S.L. Thein. 2006. Selection of housekeeping genes for gene expression studies in human reticulocytes using real-time PCR. BMC Mol. Biol. 7:33.

Skurk, T., C. Alberti-Huber, C. Herder and H. Hauner. 2007. Relationship between adipocyte size and adipokine expression and secretion. J. Clin. Endocrinol. Metab. 92(3):1023-1033.

Stevenson, R. J. 2010. An initial evaluation of the functions of human olfaction. Chem. Senses. 35(1):3-20.

Van der Steen, H.A.M., G.F.W. Prall and G.S. Plastow. 2005. Application of genomics to the pork industry. J. Anim. Sci. 83:E1-E8.

Watkins, P. J., G. Kearney, G. Rose, D. Allen, A.J.D. Ball, W. Pethick and R.D. Warner. 2014. Effect of branched-chain fatty acids 3methylindole and 4-methylphenol on consumer sensory scores of grilled lamb meat. Meat Sci. 96(2):1088-1094.

Wood, J.D. 1984. Fat deposition and the quality of fat tissue in meat animals. In .'Fats in Animal Nutrition.', (Ed. J. Wiseman), Butterworths, London. p. 407-435. 